\title{
KERUSAKAN DAN JUMLAH HEMOSIT UDANG WINDU (Penaeus monodon Fab.) YANG MENGALAMI ZOOTHAMNIOSIS
}

\section{THE DESTRUCTION AND TOTAL HAEMOCYTE COUNT OF TIGER SHRIMP (Penaeus monodon Fab.) THAT INFECTED Zoothamnium penaei (ZOOTHAMNIOSIS)}

\author{
Gunanti Maharani, Sunarti, Juni Triastuti dan Tutik Juniastuti \\ Fakultas Perikanan dan Kelautan Universitas Airlangga \\ Kampus C Mulyorejo - Surabaya, 60115 Telp. 031-5911451
}

\begin{abstract}
Tiger shrimp (Penaeus monodon Fab.) is one of the biggest non-oil and natural gas export fisheries commodity. In the other hand, the culture of this shrimp is highly affected by infectious pathogens and disease control is ciliated protozoa, Zoothamnium penaei that play an important role as ectocommensals on the body surface of tiger shrimp and causes "udang lumutan" disease.

The aim of this research are to know the destruction and mean total haemocyte count of the Tiger shrimp between healthy and easy, middle and heavy infected degree of Zoothamnium penaei. The healthy and was identified infected Zoothamnium penaei of Tiger shrimp samples collected from one of the nursery pond in Lamongan that divided of 50 healthy indivisuals and infected Zoothamnium penaei (50 individuals for each infestation degree). Haemolymph (haemocytes) was obtained from the ventral part of the haemocoel of the second abdominal segment using $1 \mathrm{ml}$ syringe filled with EDTA (Ethylene Diamine Tetra Acetic Acid). The variable observed were destruction of haemocyte and mean total haemocyte count during 7 days. ANOVA (Analysis Of Varian) was used for mean total haemocyte count change data analysis followed by Duncan's Multiple Range Test with 5\% significantly.

The research results revealed that Tiger shrimp that easy, middle and heavy infected of Zoothamnium penaei no destruction occurs, but Tiger shrimp that heavy infected of Zoothamnium penaei occurs haemocyte sitoplasma destruction. The highest mean total haemocyte count change was $61,64 \times 10^{6}$ $\pm 3,56 \times 10^{6}$ cells $\mathrm{ml}^{-1}$ in Tiger shrimp that middle infected of Zoothamnium penaei, while the lowest mean total haemocyte count change was $41,04 \times 10^{6} \pm 3,64 \times 10^{6}$ cells $\mathrm{ml}^{-1}$ occur in Tiger shrimp that heavy infected of Zoothamnium penaei.
\end{abstract}

Key words : Zoothamniosis, Penaeus monodon Fab., haemocyte

\section{Pendahuluan}

Udang merupakan salah satu bahan makanan sumber protein hewani bermutu tinggi yang sangat digemari oleh konsumen dalam negeri maupun luar negeri karena memiliki rasa yang sangat gurih dan karena kadar kolesterolnnya yang lebih rendah daripada hewan mamalia (Darmono, 1991). Salah satu jenis udang yang merupakan primadona komoditas ekspor non-migas dari sektor perikanan adalah udang windu (Penaeus monodon Fab.). Statistik ekspor hasil perikanan tahun 2003 menunjukkan bahwa selama periode 1999 - 2003, volume ekspor udang mengalami peningkatan rata-rata sebesar $6 \%$ per tahun, yaitu dari 109.651 ton pada tahun 1999 meningkat menjadi 137.635 ton pada tahun 2003 (Departemen Kelautan dan Perikanan, 2005).

Salah satu kendala yang sering muncul pada usaha pembenihan maupun pembesaran udang windu adalah timbulnya serangan penyakit. Salah satu penyakit yang sering menyerang udang windu baik di tambak maupun di panti pembenihan (hatchery) adalah patogen dari golongan ciliata, terutama dari spesies Zoothamnium sp. dan Vorticella sp. (Baticados et al., 1989 dan Mahasri, 1996). Zoothamnium sp. dan Vorticella sp. merupakan ciliata yang hidup normal pada perairan yang berkualitas, akan tetapi protozoa ini akan meningkat populasinya pada perairan dengan kualitas yang rendah. Penyebaran jenis parasit ini meliputi daerah pertambakan di seluruh Indonesia, Thailand, Malaysia, India, Cina, Jepang dan Amerika (Rukyani, 1996).

Zoothamnium sp. menyerang udang pada semua stadia mulai dari telur, larva, juvenil dan dewasa pada kondisi perairan dengan oksigen terlarut rendah (Baticados et al., 1989 dan Mahasri, 1996). Protozoa ini menyerang pada permukaan tubuh, kaki renang, kaki jalan, rostrum dan insang. Organ yang terserang akan terlihat seperti diselaputi benda 
asing berwarna putih kecoklatan. Bila terjadi infeksi berat, penempelan ini menyebar ke seluruh permukaan tubuh sehingga disebut penyakit "udang berjaket". Serangan protozoa tersebut mengakibatkan udang sulit bernafas, malas bergerak dan mencari makan (Sinderman, 1997). Sementara itu Tonguthai (1997) mengatakan bahwa udang yang terserang Zoothamnium sp. sulit ganti kulit (moulting), pertumbuhan terhambat dan menyebabkan kematian.

Sampai saat ini, pemantauan dan penelitian tentang zoothamniosis baru sampai pada gejala klinis yang nampak dan pemeriksaan yang sering dilakukan adalah dengan pengerokan (scrapping). Patogenitas Zoothamnium penaei pada udang windu yang mengalami zoothamniosis masih belum diketahui, akan tetapi Lightner (1998) sudah melakukan pemeriksaan histopatologi kulit dan insang udang windu yang mengalami zoothamniosis. Hasil yang diperoleh menunjukkan bahwa terjadi penebalan kutikula pada udang. Sementara itu, pemeriksaan tentang karakteristik hemosit udang windu yang mengalami zoothamniosis masih belum banyak dilakukan.

Fungsi dan komposisi hemosit masih belum diketahui dengan baik, sedangkan jumlah dan tipe hemosit serta aktivitas mikrobial kemungkinan dapat digunakan untuk memantau kesehatan udang. Hasil pengamatan menunjukkan bahwa komposisi darah udang windu dapat diukur dan dapat digunakan sebagai penilaian kesehatan udang melalui karakteristik dan aktivitas sistem pertahanan udang terhadap agen infeksius yang diperankan oleh hemosit (Van de Braak et al., 1996). Berdasarkan kondisi di atas, maka diperlukan studi mengenai kerusakan dan jumlah hemosit pada udang windu yang terserang penyakit yang disebabkan oleh parasit dari kelas ciliata, yaitu Zoothamnium penaei.

Berdasarkan rumusan masalah tersebut di atas, pengajuan penelitian ini bertujuan untuk mengetahui perbedaan kerusakan dan jumlah hemosit udang windu (Penaeus monodon Fab.) normal dan yang mengalami zoothamniosis pada derajat infestasi ringan, sedang dan berat.

Melalui penelitian ini diharapkan dapat memberikan informasi dan pengetahuan baru tentang bagaimana kerusakan dan jumlah hemosit udang windu (Penaeus monodon Fab.) yang mengalami zoothamniosis, sehingga dapat digunakan sebagai salah satu pedoman dalam mendiagnosis penyakit zoothamniosis pada udang windu.

\section{Materi dan Metode Penelitian}

Penelitian ini dilaksanakan pada tanggal 26 Nopember 2006 sampai dengan 26 Desember 2006 di Laboratorium Pendidikan Perikanan Pragram Studi Budidaya Perairan dan Laboratorium In Vitro Fakultas Kedokteran Hewan Universitas Airlangga Surabaya.

Peralatan yang digunakan dalam penelitian ini adalah akuarium dengan ukuran $40 \times 25 \times 30 \mathrm{~cm}^{3}$ sebanyak 4 buah yang digunakan untuk pemeliharaan stok udang windu normal dan yang terinfestasi Zoothamnium penaei, aerator, selang aerator, batu aerator dan shelter dari tali rafia. Peralatan yang digunakan untuk pembuatan preparat ulas darah adalah jaring ikan kecil, scalpel, gunting bedah, pinset, cawan petri, spuit insulin merk TERUMO volume $1 \mathrm{ml}$, object glass, cover glass, haemocytometer, handy tally counter dan mikroskop inverted.

Bahan yang digunakan dalam penelitian ini adalah udang windu (Penaeus monodon Fabricus) yang berumur $2-3$ bulan dengan berat tubuh berkisar antara $20-25$ gram sebanyak 50 ekor udang windu yang sehat dan 50 ekor udang windu sebelumnya telah diidentifikasi terinfestasi parasit Zoothamnium penaei pada kolam yang berbeda.yang diambil secara acak dari salah satu tambak pembesaran di daerah Lamongan. Pakan yang diberikan berupa pellet udang dan diberikan setiap hari selama pemeliharaan sebanyak dua kali pagi (jam 07.00) dan sore (jam 17.00) dengan dosis $5 \%$ dari berat tubuh. Sementara itu, bahan yang digunakan untuk pembuatan preparat ulas darah adalah EDTA (Ethylene Diaminetetra Acetic Acid) sebagai antikoagulan, metanol dan larutan Giemsa $10 \%$.

Penelitian ini menggunakan metode deskirptif analitik berupa perubahan kerusakan hemosit udang windu yang normal dan yang mengalami zoothamniosis pada derajat infestasi ringan, sedang dan berat. Sedangkan untuk perubahan jumlah hemosit dianalisis menggunakan ANAVA (Analisis Varian) dengan menggunakan Rancangan Acak Kelompok (RAK), dan apabila terdapat perbedaan antar derajat infestasi dilanjutkan dengan Uji Berjarak Ganda Duncan dengan taraf signifikansi $5 \%$.

Parameter utama yang diamati dalam penelitian ini adalah perubahan karakteristik dari hemosit udang windu (Penaeus monodon Fab.) yang terserang Zoothamnium penaei pada derajat infestasi ringan, sedang dan berat yang meliputi perubahan jumlah hemosit dan kerusakan hemosit udang windu. Parameter penunjang yang diamati adalah kualitas air 
(salinitas, suhu dan oksigen terlarut), perubahan warna tubuh, jumlah zooid dan lokasi organ yang terserang, cara bergerak dan cara mencari makan.

$$
\text { Derajat infestasi ditentukan }
$$

berdasarkan ketentuan Fegan et al. (1993) dalam Raya (2006) yaitu derajat serangan parasit ektokomensal (Zoothamnium sp., Vorticella sp. dan Epystilis sp.) ditentukan berdasarkan jumlah zooid pada permukaan tubuh dan insang. Klasifikasi untuk derajat infestasi ringan bila ditemukan $5-25$ zooid, derajat infestasi sedang bila ditemukan $26-50$ zooid dan derajat infestasi berat bila ditemukan lebih besar dari 50 zooid.

\section{Pengamatan patologi anatomi}

Pengamatan patologi anatomi udang windu yang terserang Zoothamnium penaei dilakukan dengan cara mengamati perubahan gejala klinis berupa perubahan warna tubuh dan organ yang terserang Zoothamnium penaei serta perubahan tingkah laku yang meliputi cara bergerak (berenang) dan mencari makan. Pengamatan dan pemantauan dilakukan setiap hari selama 7 hari pada udang windu yang normal dan udang yang terserang Zoothamnium penaei pada derajat infestasi ringan, sedang dan berat.

Penghitungan jumlah zooid Zoothamnium penaei

Penghitungan jumlah zooid Zoothamnium penaei yang menginfestasi udang windu dilakukan dengan cara scrapping pada satu sisi udang windu yang terinfestasi, yaitu pada bagian insang, cephalothorax, abdomen, kaki jalan, kaki renang dan ekor sesuai dengan organ yang terinfestasi pada masing-masing derajat infestasi (ringan, sedang dan berat).

Penghitungan jumlah hemosit

Penghitungan jumlah sel darah dilakukan dengan mengambil darah udang menggunakan spuit insulin $1 \mathrm{ml}$ yang sebelumnya sudah diberi EDTA sebagai antikoagulan. Pengambilan sampel darah dilakukan dari bagian ventral dari haemocoel, yaitu pada ruas abdomen kedua diantara kutikula (Van de Braak, 2002). Sampel darah udang windu yang diambil masing-masing sebanyak 3 ekor dari udang windu yang normal dan udang windu yang mengalami zoothamniosis pada derajat infestasi ringan, sedang dan berat setiap hari. Setelah darah diambil dari udang yang sehat maupun yang mengalami zoothamniosis tingkat ringan, sedang dan berat, darah diteteskan di atas haemocytometer dan kemudian dihitung dengan menggunakan hand tally counter dan rumus penghitungannya adalah sebagai berikut: jika dalam $1 \mathrm{ml}$ ditemukan sebanyak $\mathrm{N}$ sel, maka didapat:

\section{$\mathrm{N}$ x 25 square $\times 50 \times 10^{3}$ cells $/ \mathrm{ml}$ (Brock and Madigan, 1991).}

Keterangan:

$\mathrm{N}=$ jumlah sel

25 square $=25$ kotak kecil dalam kamar hitung haemocytometer

Pembuatan preparat ulas darah

Pengamatan hemosit udang windu yang normal dan yang mengalami zoothamniosis pada derajat infestasi yang berbeda dilakukan setiap hari. Prosedur pembuatan preparat ulas darah bedasarkan Bijanti (2005) adalah dengan mengambil sampel darah udang windu menggunakan spuit $1 \mathrm{ml}$ yang sebelumnya sudah diberi EDTA sebagai antikoagulan. Sampel darah diulaskan di atas object glass dan kemudian dikeringkan. Sampel ulas darah yang telah kering kemudian dimasukkan ke dalam larutan metanol selama 3 menit lalu dikeringkan. Sampel ulas darah dimasukkan ke dalam larutan Giemsa 10\% selama 30 menit kemudian dicuci dengan air mengalir dan dikeringkan. Setelah sampel ulas darah kering, dilakukan pengamatan di bawah mikroskop inverted dengan perbesaran 400X.

\section{Hasil dan Pembahasan}

Hasil pengamatan patologi anatomi udang windu yang mengalami zoothamniosis pada derajat infestasi rendah memiliki warna tubuh yang sama seperti warna tubuh udang windu yang normal, yaitu abu-abu kehitaman. Pada udang windu dengan derajat infestasi sedang dan berat terjadi perubahan warna tubuh pada seluruh permukaan tubuh udang windu (insang, kaki renang, kaki jalan, abdomen dan cephalothorax) yaitu warna tubuh menjadi coklat muda hingga coklat tua, karena adanya kotoran seperti kapas yang menempel dan semakin menebal. Udang windu yang normal (sehat) dapat berenang dan mencari makan dengan aktif. Sementara itu, udang windu yang mengalami zoothamniosis pada derajat infestasi ringan masih bisa berenang secara aktif dan aktif mencari makan di akuarium, sedangkan pada derajat infestasi sedang udang windu sudah kurang aktif dalam berenang dan mencari makan. Perbedaan morfologi udang windu yang normal (sehat) dan yang mengalami zoothamniosis pada derajat infestasi ringan, sedang dan berat dapat dilihat pada Gambar 1 . 


\begin{tabular}{|c|c|c|c|}
\hline $\begin{array}{c}\text { Derajat } \\
\text { Infestasi }\end{array}$ & Gambar & $\begin{array}{c}\text { Derajat } \\
\text { Infestasi }\end{array}$ & Gambar \\
\hline Normal & Sedang & Berat & \\
\hline Ringan & & & \\
\hline
\end{tabular}

Gambar 1. Morfologi udang windu (Penaeus monodon Fab.) yang normal dan yang mengalami zoothamniosis

Berdasarkan hasil penghitungan jumlah zooid udang windu yang sehat tidak ditemukan adanya zooid Zoothamnium penaei. Hasil penghitungan jumlah zooid udang windu yang mengalami zoothamniosis pada derajat infestasi ringan, peningkatan penyebaran zooid Zoothamnium penaei paling banyak ditemukan pada bagian abdomen (hari ke-1, 2, 3, 6 dan 7) yang diikuti oleh kaki renang (hari ke-1, 3, 4, 5 dan 7), kaki jalan (hari ke-2, 4, dan 5) dan cephalothorax (hari ke-6). Jumlah rata-rata infestasi zooid Zoothamnium penaei pada berbagai organ udang windu yang mengalami zoothamniosis dapat dilihat pada Tabel 1 .
Selama penelitian, pada udang windu yang normal (sehat) tidak terjadi kematian. Mortalitas udang windu yang mengalami zoothamniosis pada derajat infestasi ringan selama pemeliharaan adalah sebesar $20 \%$. Sementara itu, udang windu yang mengalami zoothamniosis derajat infestasi sedang dan berat mengalami mortalitas masing-masing sebesar $60 \%$ dan $80 \%$. Mortalitas udang windu yang mengalami zoothamniosis yang terjadi selama pemeliharaan disajikan pada Tabel 2 .

Parameter pengamatan kualitas air selama penelitian meliputi suhu, salinitas dan oksigen terlarut. Pada udang windu yang normal (sehat), pertumbuhan berada pada kisaran suhu

Tabel 1. Jumlah rata-rata infestasi zooid Zoothamnium penaei pada berbagai organ udang windu (Penaeus monodon Fab.) yang mengalami zoothamniosis

\begin{tabular}{|c|l|c|c|c|}
\hline \multirow{2}{*}{ No. } & Organ yang terinfestasi & \multicolumn{3}{|c|}{ Jumlah rata-rata zooid } \\
\cline { 3 - 5 } & & DR & DS & DB \\
\hline 1. & Cephalothorax & 3 & 5 & 8 \\
2. & Insang & - & 7 & 10 \\
3. & Abdomen & 9 & 15 & 21 \\
4. & Kaki Jalan & 5 & 7 & 11 \\
5. & Kaki Renang & 6 & 8 & 12 \\
6. & Ekor & - & 6 & 9 \\
\hline
\end{tabular}

Keterangan:

DR: derajat infestasi ringan

DS: derajat infestasi sedang

DB: derajat infestasi berat

Tabel 2. Mortalitas udang windu (Penaeus monodon Fab.) yang mengalami zoothamniosis

\begin{tabular}{|c|c|c|c|c|c|c|c|c|c|}
\hline \multirow[t]{2}{*}{ No. } & \multirow{2}{*}{$\begin{array}{l}\text { Derajat } \\
\text { Infestasi }\end{array}$} & \multicolumn{7}{|c|}{ Mortalitas udang pada hari ke- } & \multirow{2}{*}{$\begin{array}{c}\text { Persentase } \\
(\%)\end{array}$} \\
\hline & & 1 & 2 & 3 & 4 & 5 & 6 & 7 & \\
\hline 1. & Normal & 0 & 0 & 0 & 0 & 0 & 0 & 0 & 0 \\
\hline 2. & Ringan & 1 & 1 & 1 & 2 & 1 & 2 & 2 & 20 \\
\hline 3. & Sedang & 3 & 4 & 4 & 5 & 4 & 5 & 5 & 60 \\
\hline 4. & Berat & 5 & 5 & 6 & 5 & 6 & 6 & 7 & 80 \\
\hline
\end{tabular}


$28,2-28,7^{\circ} \mathrm{C}$, salinitas $8 \mathrm{ppt}$ dan oksigen terlarut 5,8 -6,0 ppm. Pada udang windu yang mengalami zoothamniosis derajat infestasi ringan memiliki kualitas air yang tidak jauh berbeda dengan udang windu yang normal, yaitu pada kisaran suhu $27,4-27,6^{\circ} \mathrm{C}$, salinitas 8 - 9 ppt, sedangkan oksigen terlarut mulai menurun yaitu 44,3 - 4,6 ppm. Pada udang windu yang mengalami derajat infestasi sedang menunjukkan kisaran suhu pada $27,4-27,6^{\circ} \mathrm{C}$, salinitas $8-9$ ppt dan oksigen terlarut $4,2-4,5$ ppm. Sementara itu, udang windu yang mengalami zoothamniosis pada derajat infestasi berat berada pada kisaran suhu $27,2-27,6^{\circ} \mathrm{C}$, salinitas $8-9$ ppt dan oksigen terlarut 4,0-4,3 ppm.

Berdasarkan hasil penelitian, jumlah rata-rata hemosit udang windu yang mengalami zoothamniosis terjadi perubahan yang nyata pada jumlah hemosit udang windu yang mengalami zoothamniosis $(\mathrm{p}<0,05)$ dibandingkan dengan udang windu yang normal (sehat). Jumlah rata-rata hemosit pada udang windu yang mengalami zoothamniosis derajat infestasi ringan dan sedang mengalami peningkatan dibandingkan dengan hemosit udang windu yang normal. Sementara itu, jumlah rata-rata hemosit udang windu yang mengalami zoothamniosis derajat infestasi berat mengalami penurunan dibandingkan dengan jumlah rata-rata hemosit udang windu yang normal. Perubahan jumlah rata-rata hemosit pada udang windu yang mengalami zoothamniosis berdasarkan hasil penelitian disajikan pada Tabel 3.

Hasil pemeriksaan kerusakan hemosit udang windu yang terinfestasi Zoothamnium penaei berdasarkan pembuatan preparat ulas darah menunjukkan bahwa tidak terjadi kerusakan hemosit pada udang windu yang mengalami zoothamniosis derajat infestasi ringan dan sedang dibandingkan dengan hemosit udang windu yang normal. Namun, pada derajat infestasi berat menunjukkan terjadi kerusakan sitoplasma pada hemosit udang windu, yaitu sitoplasma tampak bergranul (peningkatan agregasi pada sitoplasma). Gambar kerusakan hemosit udang windu yang mengalami zoothamniosis dapat dilihat pada Gambar 2.

Tabel 3. Hasil penghitungan rata-rata jumlah hemosit udang windu (Penaeus monodon Fab.) yang mengalami zoothamniosis

\begin{tabular}{|c|c|c|c|c|c|c|c|c|c|}
\hline \multirow[t]{2}{*}{$\begin{array}{l}\text { Derajat } \\
\text { infestasi }\end{array}$} & \multicolumn{7}{|c|}{$\begin{array}{l}\text { Jumlah rata-rata hemosit pada hari ke- } \\
\left(\text { dalam } 10^{6} \mathrm{sel} / \mathrm{ml}\right)\end{array}$} & \multirow[t]{2}{*}{ Total } & \multirow[t]{2}{*}{ Rata-rata $\pm \mathrm{SD}$} \\
\hline & 1 & 2 & 3 & 4 & 5 & 6 & 7 & & \\
\hline Normal & 49 & 50,25 & 46,75 & 48,25 & 47,25 & 50,75 & 51,25 & 343,5 & $49,07^{\mathrm{c}}+1,75$ \\
\hline Rit & 55,75 & 54,5 & 55,25 & 52,25 & 52,75 & 51,5 & 58,75 & 380,75 & $54,39^{\mathrm{b}} \pm 2,49$ \\
\hline Sedang & 64,75 & 63 & 62 & 59,75 & 66,75 & 56,5 & 58,76 & 431,51 & $61,64^{\mathrm{a}} \pm 3,56$ \\
\hline Berat & 46,75 & 40 & 39,5 & 43,5 & 45,75 & 36,5 & 42,25 & 294,25 & $41,04^{\mathrm{d}} \pm 3,64$ \\
\hline Total & 216,25 & 207,75 & 203,5 & 203,75 & 212,5 & 192,25 & 211,01 & 1450,01 & \\
\hline Rata-rata & 54,062 & 51,938 & 50,875 & 50,938 & 53,125 & 48,813 & 52,753 & & \\
\hline
\end{tabular}

Keterangan: superskrip yang berbeda pada kolom yang sama menunjukkan perbedaan yang nyata $(\mathrm{P}<0,05)$

\begin{tabular}{|c|l|c|c|}
\hline $\begin{array}{c}\text { Derajat } \\
\text { Infestasi }\end{array}$ & Gambar Kerusakan Hemosit & $\begin{array}{c}\text { Derajat } \\
\text { Infestasi }\end{array}$ & Gambar Kerusakan Hemosit \\
\hline Normal & Semosit & & Sedang \\
\hline
\end{tabular}

Gambar 2. Kerusakan hemosit udang windu (Penaeus monodon Fab.) yang mengalami zoothamniosis (perbesaran 400X) 
Pada udang windu yang normal, tanpa infestasi Zoothamnium penaei, udang windu dapat berenang dan mencari makan secara aktif. Sementara itu, infestasi Zoothamnium penaei yang semakin berat pada udang windu menyebabkan udang sulit bergerak (berenang) dan mencari makan karena pergerakan tubuh terhalang oleh adanya zooid Zoothamnium penaei yang menempel pada tubuh udang windu. Hal ini sesuai dengan yang dikatakan oleh Tonguthai (1991), bahwa pada kasus infeksi berat, seluruh permukaan tubuh udang ditempeli oleh zooid Zoothamnium sp., sehingga mengakibatkan udang sulit bergerak, sulit bernafas dan sulit untuk ganti kulit. Hal ini akan menyebabkan udang stres dan akan mengalami kematian.

Peningkatan jumlah zooid Zoothamnium penaei yang menginfestasi udang windu menyebabkan perubahan warna tubuh pada udang windu. Semakin banyak zooid Zoothamnium penaei yang menginfestasi maka tubuh udang windu menjadi semakin berwarna coklat tua. Hal ini sesuai dengan yang dilaporkan oleh ASEAN (2000) bahwa udang yang terinfestasi parasit jenis Zoothamnium sp. mengakibatkan tubuh udang terlihat seperti berlumut dengan warna kecoklatan dan menunjukkan discolorasi (perubahan warna) pada seluruh tubuh dan munculnya benda seperti kapas disebabkan banyaknya jumlah koloni dari organisme. Infestasi parasit ini bisa menyebabkan kematian udang, terutama pada saat udang moulting, karena udang mudah terserang patogen.

Hasil penelitian pada udang windu yang diidentifikasi terinfestasi Zoothamnium penaei pada derajat infestasi yang berbeda (ringan, sedang dan berat) menunjukkan bahwa pada derajat infestasi ringan, Zoothamnium penaei dapat ditemukan pada abdomen, kaki jalan, kaki renang dan cephalothorax. Pada derajat infestasi sedang, Zoothamnium penaei dapat ditemukan pada abdomen, cephalothorax, insang, kaki jalan, kaki renang dan ekor. Sementara itu, pada derajat infestasi berat infestasi Zoothamnium penaei sudah menyebar ke seluruh permukaan tubuh. Adanya perbedaan lokasi organ yang terinfestasi Zoothamnium penaei pada udang windu yang diamati setiap hari pada masing masing derajat infestasi menunjukkan bahwa infestasi Zoothamnium penaei terjadi secara acak. Hal ini sesuai dengan yang dilaporkan oleh Brown et al. (1993) bahwa transmisi ciliata (Epistylis sp., Vorticella sp. maupun Zoothamnium sp.) pada kolam pemeliharaan udang setelah zooid pada fase teleotroch lepas, zooid secara aktif akan mencari lokasi penyerangan yang baru.

Tingginya jumlah zooid pada bagian abdomen dibandingkan dengan organ yang lain kemungkinan disebabkan karena pada bagian abdomen ini tidak terjadi gerakan seperti pada insang, kaki renang, cephalothorax, kaki jalan dan ekor yang sering terjadi pergerakan, sehingga semakin memudahkan Zoothamnium penaei untuk menempel pada tubuh udang. Selain itu, tingginya infestasi ini disebabkan karena pada bagian abdomen merupakan bagian tubuh paling besar (luas) dibandingkan dengan bagian tubuh yang lain. Hal ini sesuai dengan yang dilaporkan oleh (Rukyani, 1996) bahwa Zoothamnium sp. menyerang seluruh permukaan tubuh, oleh karena itu serangan parasit ini sering disebut penyakit udang berjaket atau penyakit udang bersepatu atau udang lumutan. Selanjutnya dikatakan oleh Chanratchakool et al. (1995) bahwa penyakit akibat serangan Zoothamnium sp. dikenal sebagai ektocommensal fouling disease yaitu penyakit pada permukaan tubuh yang muncul disebabkan oleh infestasi parasit secara massal.

Penelitian menunjukkan bahwa kematian udang windu yang terjadi pada udang yang mengalami zoothamniosis derajat infestasi ringan lebih sedikit, yaitu $20 \%$ dibandingkan dengan udang windu yang mengalami zoothamniosis derajat infestasi sedang sebesar $60 \%$ dan derajat infestasi berat sebesar $80 \%$. Hal ini disebabkan pada udang windu yang mengalami zoothamniosis derajat infestasi ringan, jumlah zooid Zoothamnium penaei yang menginfestasi masih sedikit (pada bagian abdomen, kaki jalan, kaki renang dan cephalothorax) sehingga udang masih bisa aktif berenang dan mencari makan. Selain itu, kualitas air (suhu dan salinitas) yang masih layak memungkinkan udang untuk bisa tumbuh dan hidup. Sementara itu, jumlah zooid Zoothamnium penaei semakin meningkat dan menyebar pada seluruh organ tubuh (abdomen, kaki jalan, kaki renang, insang, cephalothorax dan ekor) pada derajat infestasi sedang dan berat sehingga menyebabkan udang tidak bisa aktif berenang dan mencari makan. Selain itu, kualitas air yang sudah mulai menurun dan tidak layak memicu semakin meningkatnya infestasi zooid Zoothamnium penaei. Hal ini mengakibatkan kondisi tubuh udang semakin lemah dan akhirnya mengalami kematian. Hal ini sesuai dengan yang dilaporkan oleh Mahasri (1996), bahwa jumlah zooid ciliata patogen (Zoothamnium sp., Vorticella sp. dan Epystilis sp.) berkorelasi positif terhadap kematian udang windu. Semakin banyak ciliata patogen yang 
menginfestasi udang windu, maka kematian udang windu juga semakin banyak. Selanjutnya dikatakan pula oleh Brown et al. (1983), bahwa kematian udang berhubungan dengan infestasi berat dari zooid ciliata.

Tingginya mortalitas pada udang windu yang mengalami zoothamniosis dipicu oleh menurunnya kualitas air, dimana Zoothamnium penaei akan menyerang udang windu pada saat kualitas air berada pada kondisi yang tidak normal, dimana udang windu dapat tumbuh optimal pada salinitas $15-30 \mathrm{ppt}$, kisaran suhu antara $28-32^{\circ} \mathrm{C}$ dan oksigen terlarut > 5 ppm (Suyanto dan Mudjiman, 2001). Parameter utama kualitas air yang memicu timbulnya Zoothamnium penaei antara lain oksigen terlarut dan bahan organik. Pada lokasi pengambilan sampel udang windu, Zoothamnium penaei muncul di tambak dengan oksigen terlarut pada kisaran 4,2 - 4,3 ppm dan bahan organik yang tinggi. Sementara itu, oksigen terlarut selama pemeliharaan udang windu berkisar antara 4,0 - 4,3 ppm dan bahan organik tinggi yang berasal dari sisa pakan dan kotoran yang ada di dasar akuarium, sehingga jumlah zooid Zoothamnium penaei semakin meningkat. Hal ini sesuai dengan yang dinyatakan oleh Sinderman (1997) bahwa infestasi Zoothamnium sp. akan meningkat pada kolam dengan kadar oksigen terlarut yang rendah, yaitu lebih kecil dari 5 ppm serta kandungan bahan organik yang tinggi.

Hasil penelitian menunjukkan bahwa peningkatan rata-rata jumlah hemosit udang windu yang tertinggi $\left(61,64 \times 10^{6} \pm 3,56 \times 10^{6}\right.$ $\mathrm{sel} / \mathrm{ml}$ ) terdapat pada derajat infestasi sedang dan rata-rata jumlah hemosit yang terendah $\left(41,04 \times 10^{6} \pm 3,64 \times 10^{6} \mathrm{sel} / \mathrm{ml}\right)$ terdapat pada derajat infestasi berat dibandingkan dengan ratarata jumlah hemosit udang windu yang normal $\left(49,07 \times 10^{6} \pm 1,75 \times 10^{6} \mathrm{sel} / \mathrm{ml}\right)$. Hal ini diduga karena pada saat udang windu mengalami zoothamniosis derajat infestasi ringan, mukus spesifik yang dikeluarkan oleh Zoothamnium penaei (Lightner, 1998) dapat ditolerir oleh kulit udang sebagai pertahanan eksternal tubuh memungkinkan terjadinya peningkatan hemosit sebagai sinyal awal adanya gangguan atau serangan infestasi parasit. Hal ini sesuai dengan pernyataan Oliver dan Fisher (1995) dalam Van de Braak et al. (1996), bahwa faktor lingkungan seperti suhu, salinitas dan oksigen terlarut dapat menyebabkan perubahan jumlah hemosit pada Crassostrea virginica di alam. Selanjutnya dikatakan pula oleh Van de Braak et al. (1996), bahwa peningkatan suhu dapat meningkatkan jumlah sirkulasi hemosit dalam hemolim dengan meningkatnya aktivitas pompa jantung.
Sementara itu, pada saat udang windu mengalami zoothamniosis derajat infestasi sedang dimana kemungkinan infeksi penyakit lain (virus atau bakteri) mulai menyerang namun metabolisme udang masih belum terganggu karena udang masih bisa berenang dan mencari makan meskipun kurang aktif sehingga tubuh udang mengadakan respon perlawanan dengan cara meningkatkan hemosit sesuai dengan kondisi untuk mempertahankan kesehatan tubuh, pada tahap ini terjadi puncak peningkatan hemosit udang windu. Hal ini sesuai dengan yang dikatakan oleh Fontaine dan Lightner (1974), bahwa meningkatnya ketahanan tubuh udang dapat diketahui dari meningkatnya aktivitas sel-sel fagosit dan hemosit. Van de Braak et al. (2002) melaporkan pula bahwa terjadi peningkatan jumlah hemosit pada jaringan hematopoetik dan limpoid setelah infeksi virus WSH 8 reaktif pada udang windu.

Selanjutnya, setelah melalui tahap puncak perlawanan yang ditandai dengan puncak peningkatan jumlah hemosit, jumlah hemosit mengalami penurunan pada udang windu yang mengalami zoothamniosis derajat infestasi berat. Hal ini kemungkinan dikarenakan pada tahap ini udang windu sudah kehabisan tenaga akibat sudah tidak bisa aktif berenang dan mencari makan yang disebabkan oleh semakin banyaknya zooid Zoothamnium penaei yang menyelimuti seluruh permukaan tubuh dan insang udang windu. Hal ini sesuai dengan pernyataan Herupradoto (2005) bahwa berdasarkan hasil pengamatan pada saat terjadi infeksi WSBV (White Spot Baculo Virus) pada udang windu, maka hemosit akan segera bergerak menuju jaringan dimana infeksi WSBV terjadi, kemudian setelah dilakukan pengukuran total hemosit dalam sistem sirkulasi, terlihat adanya penurunan jumlah total hemosit.

Hasil penelitian menunjukkan bahwa tidak terjadi kerusakan hemosit pada udang windu yang mengalami zoothamniosis pada derajat infestasi ringan dan sedang. Hal ini diduga disebabkan karena Zoothamnium penaei merupakan parasit ektokomensal, sehingga mukus spesifik yang dikeluarkan oleh Zoothamnium penaei tidak sampai masuk ke jaringan yang memproduksi sel-sel darah karena adanya kulit dan mukus sebagai penghalang fisik pada permukaan tubuh udang. Pada derajat infestasi ringan dan sedang, pertahanan tubuh udang masih memungkinkan untuk melawan serangan tersebut karena adanya respon adaptasi terhadap suatu infeksi untuk mempertahankan kondisi sel, yaitu melalui kulit (merupakan pertahanan eksternal) dan hemosit (merupakan 
pertahanan internal). Hal ini sesuai dengan pernyataan Campbell et al. (2004), bahwa kulit merupakan rintangan (penghalang) yang tidak dapat ditembus oleh mikroba dan mukus yang disekresikan oleh sel-sel membran mukosa juga menjerat mikroba dan partikel lain yang mengadakan kontak dengannya (kulit dan membran mukosa). Dengan demikian, kulit merupakan penghalang fisik yang mensekresi lisosim yang dapat merusak mikroba (Rantam, 2003).

Sementara itu, pada saat udang windu mengalami zoothamniosis derajat infestasi berat, terjadi perubahan hemosit berupa kerusakan sitoplasma, yaitu sitoplasma terlihat bergranul (peningkatan agregasi pada sitoplasma). Hal ini kemungkinan disebabkan pada saat udang windu mengalami zoothamniosis derajat infestasi berat, terjadi kerusakan (luka) fisik yang dapat memicu masuknya infeksi penyakit yang lain, seperti bakteri atau virus. Kondisi seperti ini dipicu oleh menurunnya kualitas air dan semakin menurunnya kesehatan tubuh udang, sehingga menyebabkan agen penyakit (virus atau bakteri) mudah menyerang. Hal ini sesuai dengan pernyataan Van de Braak et al. (2002) yang telah membuktikan bahwa terjadi peningkatan jumlah hemosit tipe granular di daerah infeksi WSBV (White Spot Baculo Virus).

\section{Kesimpulan}

Udang windu (Penaeus monodon Fab.) yang mengalami zoothamniosis pada derajat infestasi ringan dan sedang mengalami peningkatan rata-rata jumlah hemosit masingmasing sebesar $54,39 \times 10^{6} \pm 2,49 \times 10^{6} \mathrm{sel} / \mathrm{ml}$ dan $61,64 \times 10^{6} \pm 3,56 \times 10^{6} \mathrm{sel} / \mathrm{ml}$, sedangkan pada derajat infestasi berat hemosit udang windu mengalami penurunan sebesar $41,04 \times 10^{6} \pm$ $3,64 \times 10^{6} \mathrm{sel} / \mathrm{ml}$. Udang windu (Penaeus monodon Fab.) yang mengalami zoothamniosis pada derajat infestasi ringan dan sedang tidak menunjukkan perubahan (kerusakan) pada hemosit, namun pada derajat infestasi berat hemosit udang windu menunjukkan perubahan (kerusakan) pada sitoplasma.

Perlu adanya penelitian lebih lanjut mengenai jumlah masing-masing tipe hemosit (granular, semigranular maupun agranular) untuk mengetahui aktivitas pertahanan tubuh oleh hemosit (fagositik, enkapsulasi, sitotoksik maupun prophenoloxidase) pada udang windu yang mengalami zoothamniosis.

\section{Daftar Pustaka}

ASEAN Cooperation in Food, Agriculture and Forestry. 2000. ASEAN Good Shrimp
Farm Management Practice. Fisheries Publication Series No.1. 35p.

Baticados, M.C.L. et al. 1989. Disease of Penaeid Shrimp in The Philippines Aquaculture. Department Southeast Asian Fisheries Development Center. p. $18-20$.

Bijanti, R. 2005. Hematologi Ikan (Teknik Pengambilan Darah dan Pemeriksaan Hematologi Ikan). Buku Ajar. Bagian Ilmu Kedokteran Dasar Veteriner, Fakultas Kedokteran Hewan. Universitas Airlangga. Surabaya. hal. 22.

Brock, T.D. and Madigan, M.T. 1991. Biology of Microorganism. Sixth Edition. Prentice - Hall International.

Brown, P.B., M.R. White, D.L. Swann, and M.S. Fuller. 1993. A Severe Outbreak of Ectoparsitism Due to Epistylis sp. Journal of the World Aquaculture Society. 24(1). p.116-120.

Campbell, N.A., J.B. Reece and L.G. Mitchell. 2004. Biologi. Edisi Kelima, Jilid 3. Penerbit Erlangga. Jakarta. Hal. 73-88.

Chanratchakool, P., J.F. Trunbull, S.F. Smith and C. Limsuwan. 1995. Health Management in Shrimp Ponds. Health Research Institute. Bangkok. Thailand. p. 50-53.

Darmono. 1991. Budidaya Udang Penaeus. Kanisius. Yogyakarta. 103 hal.

Departemen Kelautan dan Perikanan. 2005. Revitalisasi Perikanan. Jakarta. 81 hal. http//www.dkp.go.id/revitalisasi/pdf. Desember, 2005.

Herupradoto, E.B.A. 2005. Analisis Protein Envelope VP28 White Spot Baculovirus Isolat Lokal Dari Udang Windu (Penaeus monodon) dan Uji Sebagai Kandidat Imunostimulan. Disertasi. Program Pascasarjana Universitas Airlangga. Surabaya. Hal. $101-102$.

Kusriningrum. 1989. Dasar Perancangan Percobaan dan Rancangan Acak Lengkap. Universitas Airlangga. Surabaya. 143 hal.

Lightner, D.V. 1998. Prevalence and Geographic Distribution of MBV and Other Disease in Cultured Giant Tiger Prawns (Penaeus monodon) in the Philippines. The Oceanic Institute. Honolulu. Hawai. p. 24-37.

Mahasri, G. 1996. Pengaruh Manipulasi Tingkat Aerasi dan Padat Tebar Terhadap Infestasi Parasit Protozoa Kelas Ciliata Pada Benur Udang Windu. Tesis. 
Institut Pertanian Bogor. Bogor. 67 hal.

1998. Hubungan Infestasi Ciliata Patogen dengan Tingkat Kematian Benih Udang Windu (Penaeus monodon Fab.). Media Kedokteran Hewan. Fakultas Kedokteran Hewan UNAIR. Vol.14, No. 6. Hal. 122 - 129.

Rantam, F.A. 2003. Metode Imunologi. Airlangga University Press. Surabaya. Hal. 1-9.

Raya, L. 2006. Gambaran Patologi Insang dan kulit Udang Windu (Penaeus monodon Fab.) Yang Terserang Ciliata Patogen Dari Famili Vorticellidae (Zoothamnium sp.). Skripsi. FKH UNAIR. Surabaya. 101 hal.

Rukyani, A. 1996. Jenis Penyakit Udang dan Tambak dan Cara Pengendaliannya. Makalah Pertemuan Aplikasi Paket Teknologi Pertanian tanggal 9-11 Januari 1996 di BIP Lampung. 17 hal.

Sinderman, C. J. 1997. Ciliata Injeslahun in Disease Diagnosist and Control in North America Marine Aquaculture. Elsevier. New York. pp. 230.

Soderhall, K. and L. Cerenius. 1992. Crustacean Immunity. Annual Review of Fish Diseases, 2. pp. 3-23.

Suyanto, S.R. dan A. Mudjiman. 2001. Budidaya Udang Windu. PT. Penebar Swadaya. Depok. 207 hal.
Tonguthai, K. 1991. Disease of the Freshwater Prawn, Macrobrachium rosenbergii. AAHRI Newsletter Article. Vol.4, No.2, December. Bangkok. Thailand.

Van de Braak, C.B.T., R. Faber and J.H. Boon. 1996. Cellular and Humoral Characteristics of Penaeus monodon Fab. Haemolymph. Comparative Haematology International. Netherlands. p.194-203. http://www.library.wur.ni/wda/disserta tion $/ 3218$.

Van de Braak, C.B.T. 2002. Haemocytic Defence In Black Tiger Shrimp (Penaeus monodon). Thesis. Wageningen Institute of Animal Sciences. Netherlands. http://www.library.wur.ni/wda/disserta tion/3218. Juny, 2002. pp. 168.

Van de Braak, C.B.T., M.H.A. Botterblom, N. Taverne, W.B. Van Muiswinkel, J.H.W.M. Rombout and W.P.W. Van der Knaap. 2002. The Roles of Haemocytes and The Lymphoid Organ In The Clearance of Injected Vibrio Bacteria in Penaeus monodon Shrimp. 2002. Thesis. Wageningen Institute of Animal Sciences. Netherlands. http://www.library.wur.ni/wda/disserta tion/3218. January, 2002. pp. 93-108. 